\title{
Uitdagingen voor bestuur en politiek op gemeenteniveau: het burgerperspectief
}

\author{
Jeroen van der Waal, Babs Broekema \& Eefje Steenvoorden
}

\begin{abstract}
Voor de legitimiteit en slagvaardigheid van overheden is het cruciaal om zicht te hebben op de zorgen van burgers omtrent de maatschappij en politiek. Op nationaal niveau worden deze zorgen al bijna tien jaar door het Sociaal en Cultureel Planbureau (SCP) systematisch in kaart gebracht via het Continu Onderzoek Burgerperspectieven (COB). Op het lokale niveau ontbreekt het aan informatie over wat burgers zorgen baart. Inzicht in lokal ervaren problemen zal in de komende jaren waarschijnlijk aan belang winnen door de recentelijke decentralisatie van nationale overheidstaken naar de gemeenten. Dit artikel gaat na welke problemen de burgers zien in hun gemeente, op basis van een analyse van gegevens uit het Lokaal Kiezersonderzoek (LKO). De auteurs vinden een aantal opvallende verschillen met de op nationaal niveau ervaren problemen in dezelfde periode. De gemeentelijke problematiek die burgers aankaarten, biedt kansen, maar toont ook de beperkte slagkracht van de gemeentelijke bestuurslaag. De bevindingen van het onderzoek wijzen al met al op de substantiële meerwaarde van het LKO ten opzichte van het reeds langer lopende COB.
\end{abstract}

\section{Inleiding}

Voor de representatieve functie van de democratie is een zekere overeenkomst tussen de zorgen van burgers en beleidsprioriteiten van overheden van groot belang (Easton, 1965; Soroka \& Wlezien, 2010). Bovendien komt inzicht in de wensen van burgers de slagvaardigheid van democratisch bestuur ten goede (Dahl, 1989), en is representatief en slagvaardig bestuur op zijn beurt goed voor het publieke vertrouwen in instituties als de politiek (Hetherington, 1998; Malhotra \& Kuo, 2008).

Voor de legitimiteit en slagvaardigheid van overheden is het kortom cruciaal om zicht te hebben op de zorgen van burgers omtrent de maatschappij en politiek. Op nationaal niveau worden deze zorgen al bijna tien jaar door het Sociaal en Cultureel Planbureau (SCP) systematisch in kaart gebracht in de serie Continu Onderzoek Burgerperspectieven (COB). Elk kwartaal verschijnt het rapport Burgerperspectieven, waarin onder andere wordt gerapporteerd over de vraag wat burgers de belangrijkste maatschappelijke problemen vinden. Zodra een rangordening in hun antwoorden wordt aangebracht, staan zaken als 'immigratie en integratie', 'samenleven', 'politiek en bestuur' en 'gezondheids- en ouderenzorg' al jaren bovenaan (Den Ridder e.a., 2017). 
Op het lokale niveau ontbreekt het echter aan informatie over wat burgers zorgen baart. En we kunnen verwachten dat inzicht in lokaal ervaren problemen in de komende jaren aan belang wint, gezien de recentelijke decentralisatie van nationale overheidstaken naar de gemeenten. Decentralisatie wordt veelal gezien als een methode om beleid accurater te kunnen afstemmen op de zorgen van burgers. Kortere lijnen tussen burger en overheid leiden, zo is de veronderstelling, tot een betere dienstverlening met betrekking tot de behoeften en wensen van de burger (Diaz-Serrano \& Rodriguez-Pose, 2015; Costa-Font \& Greer, 2016). Verschillende auteurs noemen dit dan ook als een van de redenen om bestuursverantwoordelijkheden van het landelijke naar het lokale niveau te decentraliseren sinds de jaren tachtig van de vorige eeuw (Costa-Font \& Greer, 2016: 2; Exworthy \& Powell, 2015: 136). Decentralisatie is echter niet altijd ingegeven door optimalisering van de relatie tussen burger en bestuur. Decentralisatie kent immers ook politieke gronden, zoals het verminderen van overheidsuitgaven (Costa-Font \& Greer, 2016: 7).

De decentralisatie maakt het dan ook nog belangrijker voor de lokale politiek om een goed beeld te hebben van de problemen en zorgen van burgers over hun gemeente en gemeentelijk bestuur. In dit artikel gaan we daarom na welke problemen burgers zien in hun gemeente. Hiertoe maken we onderscheid tussen typen burgers en typen gemeenten. Ook vergelijken we de lokale zorgen met de zorgen over het land als geheel, om in kaart te brengen wat lokale zorgen typeert. Ten slotte gaan we in op de spanningsvelden die we signaleren tussen lokale zorgen van burgers enerzijds en mogelijkheden van lokale politiek om hier iets aan te doen anderzijds.

In deze bijdrage voeren wij een soortgelijke analyse uit als gerapporteerd in de voornoemde Burgerperspectieven. Wij richten ons daarbij echter op de grootste problemen op lokaal in plaats van op nationaal niveau, gebruikmakend van een nieuw type survey: het Lokaal Kiezersonderzoek (LKO). Het is in het eerste kwartaal van 2016 afgenomen onder een representatieve steekproef van de Nederlandse bevolking. Meer specifiek onderzoeken wij de antwoorden die respondenten hebben gegeven op de open vraag 'Wat vindt u de belangrijkste problemen die spelen in uw gemeente?' Van de 2643 respondenten in de dataset hebben 1048 (40\%) antwoord gegeven op deze vraag. Hun antwoorden varieerden van een enkel woord tot enkele zinnen. Meestal werd slechts één probleem aangekaart, maar een substantieel deel van de antwoorden bevat een opsomming van verschillende problemen.

De open vraag heeft twee voordelen voor ons onderzoek (zie Charmaz, 2006). Ten eerste wordt het hele palet aan gepercipieerde problemen in kaart gebracht, de problemen die bij het opstellen van de vragenlijst door de onderzoekers als mogelijk irrelevant werden geacht of over het hoofd werden gezien incluis. Ten tweede formuleren burgers de problemen in hun eigen woorden, wat tot een fijnmaziger begrip van de probleemdefinitie leidt, een gewenste verrijking van het onderzoek naar de opvattingen van burgers over samenleving en politiek (Kemmers, 2017). Als een burger, bijvoorbeeld, de lokale politiek als grootste probleem ziet, formu- 
leert hij mogelijk wat hem daar precies bij dwarszit. Onder een containerterm als 'de politiek' gaat immers een heel scala aan mogelijke gepercipieerde problemen schuil, die bij een gesloten vraag met als antwoordcategorie 'de politiek' uit het zicht blijven. We leren van de analyse van een open vraag dus, in dit voorbeeld, niet alleen dat een burger 'de politiek' problematisch vindt, maar ook wat hij daaraan precies problematisch vindt.

Naast de relatief grote tijdsinspanning die gepaard gaat met de analyse van een open vraag, is een tweede mogelijk nadeel de vergelijkbaarheid van de antwoorden met andere studies naar hetzelfde thema. Dit ondervangen we in deze studie echter door een identiek codeerschema te hanteren als de studies waar we onze bevindingen mee vergelijken.

We analyseren de antwoorden in drie stappen. Allereerst rapporteren we de sociale achtergrond van de antwoordgevers. Vervolgens categoriseren, duiden en ordenen we de antwoorden, en maken we een vergelijking met antwoorden op een soortgelijke vraag, die zich op landelijke problemen in plaats van lokale problemen richt, zoals die een paar maanden eerder in hetzelfde jaar zijn gerapporteerd in het COB (Den Ridder e.a., 2016). Na de categorisering, duiding en ordening van de antwoorden bezien we de uitkomsten in het licht van de verantwoordelijkheden en mogelijkheden van bestuur en politiek op gemeenteniveau. Stemmen die overeen met de behoeften en wensen van de burgers, zodat legitimiteit en slagvaardigheid kunnen worden gewaarborgd?

\section{Het burgerperspectief op lokale problemen: prioritering en duiding}

\subsection{Welke groepen kaarten lokale problemen aan?}

Tabel 1 rapporteert per opleidingsniveau, leeftijdscategorie en geslacht het aandeel respondenten dat antwoord heeft gegeven op de open vraag 'Wat vindt $u$ de belangrijkste problemen die spelen in uw gemeente?' Uit de tabel blijkt dat hoogopgeleiden, ouderen en mannen vaker dan anderen antwoord geven op de vraag wat de belangrijkste problemen in de gemeente zijn. Zo geven hoogopgeleiden (43\%) vaker antwoord dan middelbaar opgeleiden (38\%) en laagopgeleiden (33\%), waarbij alleen het verschil met laagopgeleiden significant is. Deze patronen komen overeen met eerder onderzoek naar nationaal probleembesef, waar hoogopgeleiden aanzienlijk vaker en een langer antwoord geven (Dekker e.a., 2008). Verder blijken ouderen (43\%) significant vaker een antwoord te geven dan jongeren (34\%), en geven de mannen (41\%) significant vaker antwoord dan de vrouwen (35\%), zoals ook in het COB het geval is (vgl. Dekker e.a., 2008). ${ }^{1}$ Deze ondervertegenwoordiging van laagopgeleiden, jongeren en vrouwen heeft waarschijnlijk betekenis voor de problemen die worden aangekaart. Groepen verschil-

1 Merk op dat in een (gewogen) multivariate regressieanalyse met alle drie de sociale achtergrondkenmerken daarin opgenomen alle opleidingscategorieën van elkaar verschillen, evenals alle leeftijdscategorieën. 
Tabel 1 Sociale achtergrondkenmerken van respondenten die antwoord hebben gegeven (in \%)

\begin{tabular}{|c|c|c|c|c|c|c|c|}
\hline \multicolumn{3}{|c|}{$\begin{array}{l}\text { Per opleidingsniveau } \\
(n=2.640)\end{array}$} & \multicolumn{3}{|c|}{$\begin{array}{l}\text { Per leeftijdscategorie } \\
(n=2.643)\end{array}$} & \multicolumn{2}{|c|}{ Geslacht $(n=2.643)$} \\
\hline Laag $^{\mathrm{a}}$ & Midden & Hoog & $15-44^{b}$ & $45-64$ & 65 en ouder & Vrouwen $^{c}$ & Mannen \\
\hline 33 & 38 & 43 & 34 & 38 & 43 & 35 & 41 \\
\hline
\end{tabular}

a Verschilt significant van 'Hoog' ( $p<0,00)$.

b Verschilt significant van '65 en ouder' $(p<0,00)$.

'Verschilt significant van 'Mannen' $(p<0,00)$.

len nu eenmaal in de mate waarin ze iets problematisch vinden. In paragraaf 2.4 gaan we daar dieper op in.

\subsection{De belangrijkste lokale problemen volgens burgers}

We hebben de antwoorden op de vraag naar de belangrijkste problemen in de gemeente in categorieën ondergebracht, waarbij we zo veel mogelijk de categorieën van de eerdergenoemde COB-rapportages hebben aangehouden over nationale problemen (Den Ridder e.a., 2016). ${ }^{2}$ Het codeerschema kan worden geraadpleegd op pagina 33 van de studie Crisis in aantocht? (Dekker e.a., 2009). In de eerste twee kolommen staan het aandeel en de rangorde van de categorieën van de antwoorden over lokale problemen, en ter vergelijking geven de derde en vierde kolom het aandeel van deze categorieën bij het COB (Den Ridder e.a., 2016). ${ }^{3}$

De twee categorieën die het meeste worden genoemd, zijn 'Verkeer en fysieke leefomgeving' (22\%) en 'Politiek en bestuur' (20\%) - beide geven blijk van het belang van het LKO: het zijn lokale en concrete problemen waar mensen mee kampen, die tot op heden onderbelicht zijn in rapportages over nationale problemen. De eerste categorie bestaat uit problemen variërend van parkeerproblematiek, de staat van het wegdek, het openbaar vervoer en bereikbaarheid tot vervuiling in het algemeen en hondenpoep in het bijzonder.

Daarnaast kunnen we twee subcategorieën onderscheiden binnen deze categorie: 'Winkelaanbod' en 'Huisvesting'. De eerste omvat antwoorden over de teruglopende winkelvoorzieningen: 'leegstand van winkels', 'leegstand winkelcentrum', 'het verdwijnen van veel kleine winkeliers', 'winkelsluiting' en soortgelijke problemen worden tientallen keren genoemd. Een additionele (niet-getoonde) analyse

2 De rangordening van de probleemcategorieën is gebaseerd op het aandeel respondenten dat een probleem noemt in de betreffende categorie. Dit geldt echter niet voor de onderaan opgenomen restcategorie. De problemen van respondenten die meerdere problemen rapporteerden, zijn gewogen. Zodra een respondent bijv. drie problemen rapporteert die in drie verschillende categorieën vallen, telt elk probleem voor een derde mee.

3 Een volledig overeenkomstige categorisering bleek niet mogelijk, gezien het specifieke lokale of landelijke karakter van de aangekaarte problemen. Dit geeft aan dat onderzoek naar de lokale problemen van toegevoegde waarde is op het reeds langer lopende onderzoek naar de landelijke problemen. 
laat zien dat vooral burgers van kleine gemeenten dit vaak als een probleem ervaren. ${ }^{4}$ Kortom: 'achteruitgang centrum door o.a. winkelleegstand' is wat veel mensen in hun gemeente betreuren en als grootste probleem zien. Daarmee samenhangend omvat de categorie 'Verkeer en fysieke leefomgeving' ook antwoorden over 'leegloop' en 'krimp'.

De tweede subcategorie maakt zelfs $6 \%$ van het totaal aantal antwoorden uit: 'Huisvesting'. In deze categorie gaan de antwoorden zo goed als allemaal over het 'aanbod sociale huurwoningen', 'de wachttijd' of 'beschikbaarheid' voor die woningen, en een enkele keer worden daarbij sociale categorieën als 'jongeren', 'studenten', 'werklozen' en 'eigen Nederlandse inwoners' genoemd.

De tweede grote categorie is die van 'Politiek en bestuur'. Deze categorie bestaat voor het overgrote deel uit antwoorden waarin de integriteit en kwaliteit van lokale bestuurders en politici worden betwijfeld, of hun beslissingen en prioriteiten in het algemeen als onjuist worden bestempeld. Het gaat daarbij nadrukkelijk niet om specifiek beleid op deelterreinen (dat in onze categorisatie is ingedeeld bij het desbetreffende deelgebied). Antwoorden als 'de enorme schuld van de gemeente door verkeerde keuzes' zijn gecategoriseerd onder 'Inkomen en economie', omdat de economische positie van de gemeente als belangrijkste probleem wordt opgegeven. Dit is een uiting van ontevredenheid over de bestuurlijke praktijk die niet is ondergebracht in de categorie 'Politiek en bestuur'. De politieke onvrede is dus groter dan uit de omvang van de categorie blijkt.

Er zijn opvallende geografische verschillen in het percentage respondenten dat de politiek als probleem van hun gemeente noemt: in de vier grootste steden ligt dit aanzienlijk lager (14\%) dan in kleinere en/of landelijke gemeenten (29\%). Anders verwoord: in kleinere en/of landelijke gemeenten is de categorie 'Politiek en bestuur' verreweg de grootste categorie. In de conclusies gaan we dieper in op deze saillante bevinding.

Een aanzienlijk deel van de mensen verwijt het lokale bestuur en de lokale politiek laakbaar gedrag, en ziet dat als het grootste probleem van de gemeente: kwalificaties als 'vriendjespolitiek', 'megalomanie' en 'hoogmoed' worden relatief vaak gebruikt, maar ook mildere kwalificaties als 'niet transparant zijn', 'trage besluitvorming', 'slechte communicatie' en 'adolescent gekissebis' zien we vaak terug. Deze antwoorden laten zien dat volgens velen de kwaliteit en slagvaardigheid van lokale bestuurders en politici te wensen overlaten. Veel burgers is het voorts een doorn in het oog dat gemeentebesturen 'teveel geld uitgeven aan onnodige zaken', of het zelfs 'weggooien' of 'over de balk smijten'. Het is echter belangrijk om twee kanttekeningen te plaatsen bij het hoge aandeel genoemde problemen rondom 'Politiek en bestuur'.

4 Een exploratieve analyse toont dat het aandeel antwoorden in veel categorieën niet significant verschilt tussen gemeenten die variëren in de mate van stedelijkheid, gemiddelde WOZ-waarde en het aandeel niet-westerse allochtonen (vgl. Van der Waal \& Steenvoorden, 2016). Daarom rapporteren we deze exploratieve analyse niet in haar geheel, maar besteden we in de lopende tekst alleen aandacht aan enkele significante en betekenisvolle verschillen. 
Ten eerste betreffen de antwoorden rondom 'Politiek en bestuur' niet allemaal de lokale politiek, maar soms eerder nationale politieke beslissingen. Enkele respondenten betreuren bijvoorbeeld 'schaalvergroting' en 'samenvoeging' van gemeenten zonder daarbij een verwijt te maken aan lokale politieke en bestuurlijke actoren. Ook het gebrek aan 'menskracht' of middelen voor de 'inrichting [en] overheveling [van] taken op [het] gebied van werk, gezondheidszorg e.d. naar gemeente' baart enkelen zorgen: 'Men zal in Nederland meer verantwoordelijkheid moeten nemen op het niveau waar het hoort en niet doorschuiven naar decentrale overheden.' Verschillende respondenten zien politieke en bestuurlijke vraagstukken dus als de belangrijkste problemen van de gemeente, omdat lokale politici en bestuurders niet de middelen krijgen om de verantwoordelijkheden te dragen die met decentralisatie gepaard gaan.

Ten tweede vermoeden we dat de vraagstelling 'Wat vindt u de belangrijkste problemen die spelen in uw gemeente?' mensen extra geprikkeld heeft om politieke en bestuurlijke problemen te rapporteren. Mogelijk ligt de oorzaak hiervoor in de meerduidige term 'gemeente'. Het wordt immers niet alleen gebruikt voor de aanduiding van een geografische eenheid, maar ook als aanduiding van het (gemeente)bestuur, of de gemeentelijke instellingen tezamen. Antwoorden als 'Ik heb geen flauw benul. Ik ben de afgelopen jaren werkelijk elke vorm van politiek bewustzijn verloren. Ik walg van de politici en alle ambtenaren (...)' en 'mijn gemeente is bar slecht voor mijn medebewoners, omdat de partijen ondanks veel beloften, niets uitvoeren' doen vermoeden dat verschillende mensen de vraag naar de belangrijkste problemen in 'uw gemeente' hebben geïnterpreteerd als een vraag naar het functioneren van het politiek-bestuurlijke gemeenteapparaat. Korte antwoorden als 'hoogmoed', 'het eigenbelang' en 'geen professionele aanpak' doen dat ook. Kortom: mogelijk heeft de vraagstelling het percentage problemen dat wordt genoemd omtrent 'Politiek en bestuur' vergroot. Ook kan de titel van de vragenlijst 'Politiek en beleid in uw gemeente' een rol hebben gespeeld.

Naast de twee grootste categorieën volgen er drie van elk rond de $10 \%$ van de gerapporteerde problemen: 'Criminaliteit en veiligheid', 'Immigratie en integratie' en 'Gezondheids- en ouderenzorg'. De meest gegeven antwoorden in de eerste categorie bestaan uit woorden als 'criminaliteit' en 'veiligheid'. Het is geen verrassing dat burgers in de grote steden vaker criminaliteit en veiligheid als grootste probleem rapporteren dan burgers in kleinere gemeenten. Bij immigratie en integratie gaat het overgrote deel van de antwoorden over 'asielzoekers', 'asielbeleid', 'opvang vluchtelingen' en 'AZC'. Daarnaast worden 'buitenlanders', 'allochtonen' en 'Marokkanen' als grootste probleem aangestipt. Enerzijds wordt een enkele keer iets gerapporteerd als 'de weerstand tegen het AZC vind ik een kwalijke zaak', 'verrechtsing m.b.t. tot vluchtelingenbeleid' en 'groeiend racisme', anderzijds zijn er ook geluiden als 'dat er van alles voor de allochtonen geregeld en gesubsidieerd wordt...' In de categorie 'Gezondheids- en ouderenzorg' gaat het heel vaak over 'ouderenzorg', 'PGB', 'WMO' en problemen in 'de thuiszorg'. Antwoorden waarin 'vergrijzing' als belangrijkste probleem centraal staat, zijn ook in deze categorie ondergebracht. 
De overige inhoudelijke categorieën beslaan samen $16,4 \%$. We lopen ze kort langs. Bij 'Inkomen en economie' gaat het om het 'financiële tekort' en de 'financiële middelen' van de gemeente, maar ook om zorgen over 'armoede', 'sociale verschillen' en 'de ongelijkheid tussen de nogal rijke en de andere bewoners'. De meeste antwoorden in de categorie 'Jeugd en gezin' gaan over 'hangjongeren' en over 'de jeugdzorg'. Zaken rond 'Samenleven en normen en waarden' zijn het algemene sociale klimaat - bijvoorbeeld 'saamhorigheid', 'betrokkenheid', 'sociale cohesie' en 'kloof tussen culturen' - en de rol van religie: 'de hoorbare oproep tot gebed' en 'er wordt weinig of geen rekening gehouden met wat Gods woord, de Bijbel, ons leert'. In de categorie 'Natuur en milieu' vallen 'luchtvervuiling' en 'duurzaamheid', maar ook klachten rond bodemverzakking, windmolens en gaswinning. De antwoorden onder 'Werkgelegenheid' zijn heel eenduidig: 'werkloosheid', 'werkgelegenheid' en 'weinig banen'. Helaas weten we niet of dit probleem minder vaak wordt aangekaart dan enkele jaren terug. Als dit niet het geval is, wordt werkgelegenheid blijkbaar niet als een lokaal probleem gezien. Wanneer dit wel het geval is, weerspiegelt deze kleine categorie het verbeterde economische klimaat ten opzichte van enkele jaren terug. In de categorie 'Sociaal stelsel' worden 'de bijstand', 'pensioen' en 'sociale voorzieningen' aan de orde gebracht, alsmede pleidooien voor het bijstaan van sociaal zwakkeren. Een enkeling neemt aanstoot aan 'mensen die niet willen werken', of stelt 'dat er behoorlijk wat personen in de bijstand/WW zitten die er niet horen te zitten'. De kleinste categorie 'Onderwijs, innovatie, kunst en cultuur' bevat enkele opmerkingen over 'culturele activiteiten', 'kunstbeleid' en 'onderwijs'.

De restcategorie bevat tientallen mensen die de vraag 'Wat vindt u de belangrijkste problemen die spelen in uw gemeente?' beantwoorden met 'geen idee' of 'weet ik niet', regelmatig omdat ze zich 'er niet zo mee bezig houden' of hier 'pas wonen'. Enkele tientallen respondenten geven aan dat er 'geen' of 'geen grote problemen' zijn in hun gemeente. Ten slotte blijken de antwoorden van een kleine honderd burgers moeilijk te categoriseren of duiden. Meestal omdat ze meerduidig zijn, zoals 'leefbaarheid' of 'verandering, modernisering, globalisering'. Omdat niet duidelijk is welk aspect, of welke aspecten, de respondenten hiervan problematisch vinden, is het ook niet duidelijk in welke categorie ze moeten worden geplaatst.

\subsection{Lokale versus landelijke problematiek}

Om inzicht te krijgen in de mate waarin gemeentelijke problemen die burgers rapporteren, afwijken van landelijke problemen die zij rapporteren, vergelijken we in tabel 2 de uitkomsten van het LKO met die van het COB van januari 2016.

Voor drie antwoordcategorieën geldt dat ze groter zijn op lokaal niveau dan op landelijk niveau: 'Verkeer en fysieke leefomgeving', 'Politiek en bestuur' en 'Criminaliteit en veiligheid'. De eerste categorie is de grootste op lokaal niveau met $21,8 \%$ van de antwoorden, terwijl op landelijk niveau slechts $2 \%$ van de antwoorden daaronder valt. De antwoorden in deze categorie gaan over concrete lokale problemen. Het is daarom niet opmerkelijk dat ze op landelijk niveau minder, of 
Tabel 2 Belangrijkste problemen op gemeentelijk en landelijk niveau gecategoriseerd (in \% en in rangorde)

\begin{tabular}{|c|c|c|c|c|}
\hline \multirow[t]{2}{*}{ Belangrijkste problemen } & \multicolumn{2}{|c|}{ Gemeentelijk } & \multicolumn{2}{|l|}{ Landelijk } \\
\hline & Aandeel & Rangorde & Aandeel & Rangorde \\
\hline Verkeer en fysieke leefomgeving & 22 & $\mathrm{I}$ & 2 & 9 \\
\hline - subcategorie winkelaanbod & 2 & & & \\
\hline - subcategorie huisvesting & 6 & & & \\
\hline Politiek en bestuur & 20 & 2 & 10 & 4 \\
\hline Criminaliteit en veiligheid & 11 & 3 & 4 & 7 \\
\hline Immigratie en integratie & 11 & 4 & 30 & I \\
\hline Gezondheids- en ouderenzorg & 8 & 5 & II & 3 \\
\hline Inkomen en economie & 5 & 6 & 10 & 4 \\
\hline Jeugd en gezin & 2 & 7 & I & 12 \\
\hline Samenleven en normen en waarden & 2 & 8 & 13 & 2 \\
\hline Natuur en milieu & 2 & 9 & 2 & 9 \\
\hline Werkgelegenheid & 2 & 10 & 5 & 6 \\
\hline Sociaal stelsel & 2 & II & 2 & 9 \\
\hline Onderwijs, innovatie, kunst en cultuur & 1 & 12 & I & 12 \\
\hline Internationaal/Nederland in de wereld & n.v.t. & n.v.t. & 3 & 8 \\
\hline Nederlandse tradities & n.v.t. & n.v.t. & I & 12 \\
\hline Vrijheden & n.v.t. & n.v.t. & 0 & 13 \\
\hline Weet niet; geen mening; geen problemen; overig & 13 & & 3 & \\
\hline
\end{tabular}

zelfs niet, worden aangekaart. Dit is wederom een validering van het lokale karakter van de vraag 'Wat vindt $\mathrm{u}$ de belangrijkste problemen die spelen in uw gemeente?' Voor de categorie 'Criminaliteit en veiligheid' geldt iets soortgelijks: daar komen mensen concreet mee in aanraking op lokaal niveau.

Vier probleemcategorieën blijken beduidend groter op landelijk niveau dan op lokaal niveau: 'Immigratie en integratie', 'Samenleven en normen en waarden', 'Inkomen en economie' en 'Werkgelegenheid'. De eerste bevat op landelijk niveau niet minder dan 30\% van de antwoorden, en op lokaal niveau 'slechts' 9\% van de antwoorden. Dat is een opmerkelijk groot verschil. Blijkbaar worden vraagstukken rond immigratie en integratie niet als een specifiek lokaal probleem gezien. Wat ook een rol zou kunnen spelen, is de onevenredige verdeling van asielzoekerscentra over gemeenten: in gemeenten waar amper tot geen asielzoekers worden opgevangen, wordt dit wellicht niet als probleem aangekaart. De bulk van de antwoorden in de categorie 'Immigratie en integratie' ging immers over vluchtelingenproblematiek.

De categorie 'Samenleven en normen en waarden' is op lokaal niveau amper gevuld, maar omvat op nationaal niveau $13 \%$ van de antwoorden. Waarschijnlijk hebben deze problemen minder te maken met lokale problematiek, en meer met 
een algemeen maatschappelijk of cultureel klimaat. Dit valideert de vraag naar problemen op lokaal niveau: de respondenten noemen geen nationale problemen. Ten slotte blijken de categorieën 'Inkomen en economie' en 'Werkgelegenheid' ook groter op nationaal niveau dan op lokaal niveau. Net als bij 'Samenleving en normen en waarden' vermoeden we dat economische voorspoed en de daarmee gepaard gaande werkgelegenheid door de burgers vooral als een landelijk fenomeen worden gezien. Dat is overigens opmerkelijk, gezien de grote lokale verschillen in werkloosheid die zelfs een klein land als Nederland telt (Van der Waal, 2015).

Concluderend kunnen we vaststellen dat burgers lokaal andere problematiek zien dan wel als het meest zorgelijk ervaren dan op nationaal niveau. Verschillende problemen die veel burgers als belangrijk aanmerken, zijn lokaal van aard, zoals verkeer en fysieke leefomgeving en criminaliteit en veiligheid. De antwoorden die onder die categorieën vallen, duiden over het algemeen op zaken die vallen onder het takenpakket van het gemeentelijk apparaat, variërend van het onderhoud van wegen en groenvoorzieningen tot de politie. Dit toont de waarde van het LKO, aangezien dergelijke gegevens voorheen niet op deze schaal voorhanden waren.

\subsection{Achtergrondkenmerken van de antwoordgevers}

Tabel 1 toonde dat hoogopgeleiden, ouderen en mannen vaker antwoord gaven op de vraag 'Wat vindt u de belangrijkste problemen die spelen in uw gemeente?' De resultaten in de vorige paragrafen kunnen daardoor vertekend zijn: als, bijvoorbeeld, lageropgeleiden andere problemen zouden noemen dan hogeropgeleiden, en het vooral hogeropgeleiden zijn die antwoord geven op deze vraag, dan dempt dat de percentages van problemen die laagopgeleiden noemen. Anders verwoord: door zo'n vertekening wordt het relatieve belang van een probleem in tabel 2 mogelijk onder- of overschat. Voor een goede afstemming tussen de probleemdefinities van burgers enerzijds en beleidsprioriteiten van gemeenten anderzijds is zicht op zulke onder- en overschattingen van belang. We onderzoeken daarom of sociale achtergrondkenmerken samenhangen met de gerapporteerde antwoorden.

Bij opleiding blijkt dat nauwelijks het geval. Alleen bij de categorie 'Criminaliteit en veiligheid' is sprake van significante verschillen tussen opleidingsgroepen: laagopgeleiden kaarten minder vaak problemen aan die in die categorie vallen dan middelbaar en hoogopgeleiden. ${ }^{5}$ Aangezien hoogopgeleiden oververtegenwoordigd zijn bij de antwoordgevers is de categorie 'Criminaliteit en veiligheid' daarom waarschijnlijk wat groter uitgevallen. De eerder gerapporteerde grotere weerstand tegen immigranten onder laagopgeleiden (De Koster \& Van der Waal, 2014) leidt echter niet tot het vaker aankaarten van immigratie en integratie als belangrijk probleem in hun gemeente. En hun lagere vertrouwen in de politiek en politici (Steenvoorden, 2009; Van der Waal e.a., 2017) vertaalt zich ook niet in het vaker aankaarten van politiek en bestuur als belangrijkste probleem.

5 Dit is in lijn met de bevinding dat zij zich veiliger voelen dan hoogopgeleiden, en minder vaak rapporteren slachtoffer te zijn van een delict (CBS, 2016). 
Leeftijd lijkt een belangrijkere rol te spelen: bij enkele categorieën is er sprake van leeftijdsverschillen. Zo zien jongeren minder problemen op het vlak van politiek en bestuur. Jongeren rapporteren over het algemeen minder wantrouwen in de politiek en politici dan ouderen (Dekker e.a., 2009; Van der Waal e.a., 2017), wat hier debet aan kan zijn. Ook kaarten jongeren minder vaak de zorg als probleem aan. Wij vermoeden dat zorg bij hen minder op het netvlies staat omdat ze daar minder vaak van afhankelijk zijn. Criminaliteit en veiligheid, immigratie en integratie, en inkomen en economie zien zij daarentegen vaker als belangrijk probleem in hun gemeente. Gezien hun grotere kans op slachtofferschap is het eerste niet vreemd (CBS, 2016), maar dat ze immigratie en integratie vaker aankaarten, is opmerkelijk gezien hun, over het algemeen, lagere weerstand tegen migranten (De Koster \& Van der Waal, 2014). ${ }^{6}$ De categorie 'Inkomen en economie' is minder eenduidig - omdat deze zowel bezuinigingen, financiële tekorten en het problematiseren van ongelijkheid en armoede omvat - en de reden waarom jongeren die vaker aankaarten als belangrijk probleem is daarom niet goed te duiden.

Van verschillen tussen mannen en vrouwen is alleen sprake bij de categorieën 'Politiek en bestuur' en 'Gezondheids- en ouderenzorg'. De eerste wordt vaker als probleem aangekaart door mannen, de tweede juist door vrouwen, net als in eerder onderzoek het geval was (Dekker \& Steenvoorden, 2008). Een mogelijke verklaring voor dat laatste is dat vrouwen vaker zorgtaken, zoals mantelzorg, op zich nemen dan mannen.

Samenvattend lijken de consequenties van de gevonden verschillen tussen opleidingsgroepen (gering), leeftijdsgroepen (substantieel) en geslacht (beperkt) voor het aantal keer dat problemen genoemd zijn niet groot. Dat neemt niet weg dat bijvoorbeeld het percentage mensen dat problemen heeft met politiek en bestuur wellicht wat lager is dan uit tabel 3 blijkt. Jongeren en vrouwen noemen dat probleem namelijk minder vaak dan ouderen en mannen, terwijl ze ook minder vaak antwoord geven op deze vraag. Over de hoge positie van criminaliteit en veiligheid daarentegen valt moeilijk iets te zeggen: lageropgeleiden zouden dit probleem minder vaak genoemd hebben, jongeren weer wat vaker. Het is hierbij dus niet goed te voorspellen wat er zou gebeuren als die groepen ook massaal antwoord zouden hebben gegeven op de gestelde vraag.

\section{Lokale oplossingen voor lokale problemen?}

De vorige paragraaf biedt inzicht in de zorgen en wensen van de burgers op lokaal niveau. In deze paragraaf gaan we in op zowel kansen als spanningsvelden tussen deze zorgen en wensen van burgers enerzijds en het handelingsperspectief voor gemeentelijke politiek anderzijds.

6 De mogelijkheid bestaat echter dat hun antwoorden in die categorie minder vaak gedreven zijn door zulke weerstand. De categorie 'Immigratie en integratie' bevat immers ook - aanzienlijk minder - antwoorden waaruit zorgen om het welbevinden in plaats van weerstand tegen migranten blijken. 
Tabel 3 Belangrijkste problemen naar opleiding, leeftijd en geslacht (in $\% ; n=1048)^{a}$

\begin{tabular}{|c|c|c|c|c|c|c|c|c|}
\hline & \multicolumn{3}{|c|}{ Per opleidingsniveau } & \multicolumn{3}{|c|}{ Per leeftijdscategorie } & \multicolumn{2}{|l|}{ Geslacht } \\
\hline & Laag & Midden & Hoog & $15-44$ & $45-64$ & $\begin{array}{l}65 \text { en } \\
\text { ouder }\end{array}$ & Vrouwen & Mannen \\
\hline $\begin{array}{l}\text { Verkeer en } \\
\text { fysieke leef- } \\
\text { omgeving }\end{array}$ & 26 & 25 & 30 & 26 & 23 & 33 & 25 & 29 \\
\hline $\begin{array}{l}\text { Politiek en } \\
\text { bestuur }\end{array}$ & 21 & 23 & 20 & $16^{c}$ & 22 & 28 & $18^{e}$ & 24 \\
\hline $\begin{array}{l}\text { Criminaliteit } \\
\text { en veiligheid }\end{array}$ & $10^{\mathrm{b}}$ & 19 & 19 & $20^{c}$ & 17 & $9^{d}$ & 16 & 17 \\
\hline $\begin{array}{l}\text { Immigratie en } \\
\text { integratie }\end{array}$ & 12 & 18 & 13 & $19 c$ & 13 & 11 & 15 & 14 \\
\hline $\begin{array}{l}\text { Gezondheids- } \\
\text { en ouderen- } \\
\text { zorg }\end{array}$ & 12 & 8 & 10 & $7^{c}$ & 10 & 13 & $12^{\mathrm{e}}$ & 7 \\
\hline $\begin{array}{l}\text { Inkomen en } \\
\text { economie }\end{array}$ & 7 & 8 & 10 & $1 I^{c}$ & 8 & 5 & 8 & 8 \\
\hline
\end{tabular}

${ }^{a}$ De rapportage van de problemen is hier niet gewogen zoals toegelicht in noot 2 . Ook als een respondent meerdere problemen rapporteert, telt elk door hem/haar gerapporteerd probleem volledig mee.

b Categorie 'Laag' verschilt significant van de andere categorieën $(p<0,05)$.

' Categorie ' $15-45$ ' verschilt significant van categorie '65 en ouder' $(p<0,05)$.

d Categorie '65 en ouder' verschilt significant van categorie '45-64' $(p<0,00)$.

e Verschilt significant van 'Mannen' $(p<0,05)$.

\subsection{Kansen: lokale oplossingen voor lokale problemen}

Verschillende problemen die veel burgers als belangrijk aanmerken, zijn lokaal van aard, zoals 'Verkeer en fysieke leefomgeving' en 'Criminaliteit en veiligheid'. De antwoorden in die categorieën betreffen veel zaken die vallen onder het takenpakket van het gemeentelijk apparaat, variërend van het onderhoud van wegen en groenvoorzieningen tot de politie. Het is dan ook precies op deze beleidsterreinen dat de lokale politiek de vruchten kan plukken van de nabijheid tot de burgers die zij bedient. Hoewel het voor de hand ligt dat het LKO te algemeen is om juist over de specifieke zorgen van de eigen burgers meer informatie te krijgen, geeft het aan dat hier een kans voor de gemeentelijke politiek ligt door in te gaan op lokale problemen rondom verkeer, criminaliteit en veiligheid, en de mogelijke verbeteringen op deze vlakken.

\subsection{Kansen en uitdagingen: lokale oplossingen voor omstreden lokale politiek?}

De wat omvang betreft tweede categorie lokale problemen zoals aangekaart door respondenten betreft 'Politiek en bestuur' en omvat voornamelijk uiteenlopende negatieve kwalificaties over de integriteit, professionaliteit en bekwaamheid van lokale politici. Enerzijds biedt dit, net als lokale problemen rondom 'Verkeer en fysieke leefomgeving' en 'Criminaliteit en veiligheid', kansen. Namelijk de aanwijzing waar de onvrede bij burgers ligt als het gaat om de lokale politiek, en de aan- 
sporing daar verbetering te bewerkstelligen. Anderzijds verhoudt de grote onvrede over de lokale politiek zich slecht tot het idee dat kortere lijnen tussen burger en overheid leiden tot een meer legitieme overheid (Diaz-Serrano \& Rodriguez-Pose, 2015; Costa-Font \& Greer, 2016) en de bevinding dat vertrouwen in lokale politieke instituties groter is dan in nationale of Europese politieke instituties, en burgers tevredener zijn met de lokale en de Nederlandse democratie dan met de Europese democratie (Van der Meer, 2016). Uit onze analyses blijkt de onvrede met politiek en bestuur daarentegen omgekeerd evenredig aan de afstand die zij hebben tot de burger. Lokaal bestuur en politiek worden niet alleen vaker als grootste probleem gezien dan landelijk bestuur en politiek, zij worden ook vaker als grootste probleem gezien naarmate gemeenten kleiner worden. Kortom, hoe dichter bij de burger, hoe groter de onvrede. Dat veel burgers de lokale politiek en democratie relatief positief waarderen, terwijl tegelijkertijd veel burgers de lokale politiek als grootste probleem van hun gemeente beschouwen, is opmerkelijk en vraagt om nadere duiding die buiten de reikwijdte van dit onderzoek valt. Onze bevindingen wijzen in ieder geval in de richting dat er vooral voor kleinere gemeenten een uitdaging ligt om de kloof tussen burger en politiek te dichten.

\subsection{Uitdagingen: lokale problemen, bovenlokale ontwikkelingen}

Hoewel er voor de lokale politiek kansen liggen bij sommige problemen in de categorie 'Verkeer en fysieke leefomgeving', vallen hier ook problemen onder waar de lokale politiek moeilijk zelf het hoofd aan kan bieden. Hierbij willen we in het bijzonder de geproblematiseerde leegloop en krimp van de kleinere en landelijke gemeenten noemen, en de daarmee gepaard gaande leegstand van winkels en teruglopende voorzieningen. Dit zijn problemen die de gemeentelijke politiek overstijgen. De ontwikkeling van (rand)stedelijke groei enerzijds en de krimp van meer perifere gebieden anderzijds kunnen niet door gemeenten alleen worden opgepakt. De mogelijkheden van lokale politici om deze zorgen bij burgers weg te nemen zijn dan ook beperkt.

Hetzelfde geldt voor problemen die mensen lokaal ervaren rondom immigratie. Juist de verantwoordelijkheid voor het plaatsen van asielzoekerscentra - wat veel respondenten als groot probleem aankaarten - ligt niet in de eerste plaats bij de lokale politiek. Ook hier geldt dat de lokale politiek geconfronteerd wordt met zaken die de gemeenten ver overstijgen, maar waarover hun burgers juist erg bezorgd zijn. Het geeft aan dat burgers juist op het lokale niveau landelijke of zelfs internationale uitdagingen voelen en beleven. Dit betekent dat op deze terreinen juist ook de nationale en provinciale politiek lering kunnen trekken uit onze analyse van het LKO. Het betekent echter ook dat de lokale politiek op deze terreinen weinig handelingsperspectieven heeft, terwijl die veel burgers nu juist op lokaal niveau bezighouden.

Een soortgelijke spanning zien we ook deels terug bij de problemen die worden genoemd onder 'Politiek en bestuur'. Weliswaar geeft de rapportage van verschillende problemen in die categorie kansen tot verbetering, zoals boven uiteengezet, 
maar dat geldt niet voor problemen die burgers rapporteren omtrent de decentralisatie en/of het gebrek aan financiële middelen op lokaal niveau. Deze problemen vloeien voort uit nationale politieke keuzes en zijn dus wederom lastig voor de lokale politiek om aan te pakken.

\section{Conclusies}

Een kleine tien jaar geleden begon het SCP de serie Continu Onderzoek Burgerperspectieven (COB). Daarin wordt elk kwartaal onder andere gerapporteerd wat burgers als de belangrijkste problemen van Nederland beschouwen. In navolging daarvan rapporteert deze studie wat burgers als de belangrijkste problemen in hun gemeente beschouwen, gebaseerd op hun antwoorden op de open vraag 'Wat vindt u de belangrijkste problemen die spelen in uw gemeente?' in het recent gelanceerde LKO. Bij de analyse van die antwoorden hebben we het in het COB gehanteerde codeerschema aangehouden. Deze studie is daarmee de lokale pendant van het landelijke COB.

Iets meer dan $40 \%$ van de lokale problemen die burgers rapporteren, valt onder de twee grootste categorieën, die qua omvang ongeveer even groot zijn: 'Verkeer en fysieke leefomgeving' en 'Politiek en bestuur'. De drie ongeveer even grote categorieën die daarop volgen, omvatten bijna een derde van de antwoorden: 'Criminaliteit en veiligheid', 'Immigratie en integratie' en 'Gezondheids- en ouderenzorg'. Andere categorieën omvatten slechts enkele procenten.

We vinden een aantal opvallende verschillen met de op nationaal niveau ervaren problemen in dezelfde periode (Den Ridder e.a., 2016). Problemen rondom 'Verkeer en fysieke leefomgeving', 'Politiek en bestuur' en 'Criminaliteit en veiligheid' worden op lokaal niveau aanzienlijk vaker genoemd dan op nationaal niveau, en hebben een duidelijk lokaal karakter. Deze problematiek valt daarmee buiten het zicht van onderzoek dat vraagt naar wat burgers op nationale schaal als grootste probleem zien. Het LKO brengt aan het licht dat problemen betreffende verkeer, de fysieke leefomgeving, criminaliteit en veiligheid belangrijker zijn in de belevingswereld van burgers dan tot op heden op basis van het onderzoek gerapporteerd in het COB kan worden vermoed.

Een ander opvallend verschil is dat een vijfde van de respondenten de belangrijkste problemen ontwaart binnen de categorie 'Politiek en bestuur', terwijl dit op landelijk niveau slechts een tiende is. En hierbij vinden we ook grote lokale variatie. Waar in de vier grootste steden 'slechts' $14 \%$ problemen rondom politiek en bestuur noemt, loopt dit op tot bijna een derde in kleinere en landelijke gemeenten. Deze saillante bevinding staat haaks op het algemene patroon dat het vertrouwen in de politiek op lokaal niveau groter is dan het vertrouwen in de politiek op landelijk en Europees niveau (Dekker e.a., 2016; Van der Meer, 2016). Daarmee suggereert onze studie dat, in tegenstelling tot wat vaak wordt beweerd (Diaz-Serrano \& Rodriguez-Pose, 2015; Costa-Font \& Greer, 2016), de politiek dichter bij de burger brengen geen panacee is voor het verhogen van haar legiti- 
miteit onder de bevolking. Vervolgonderzoek kan zich richten op de vraag waarom in kleine en landelijke gemeenten de burgers de lokale politiek zoveel vaker problematischer vinden dan in de grote steden. Een mogelijke verklaring kan liggen in een sterkere professionalisering van de politiek in grotere gemeenten.

Antwoorden vallend onder de categorieën 'Immigratie en integratie', 'Samenleven en normen en waarden', 'Inkomen en economie' en 'Werkgelegenheid' komen op lokaal niveau aanzienlijk minder vaak voor dan op nationaal niveau. Veel van de gerapporteerde problemen in de eerste categorie gaan over vluchtelingen en asielzoekerscentra. Dat dit meer als een nationaal dan een lokaal probleem wordt gezien, kan te maken hebben met de onevenredige verdeling over gemeenten. Burgers wonend in gemeenten waar relatief weinig vluchtelingen worden opgevangen, rapporteren problemen daaromtrent allicht minder vaak als het grootste probleem waar hun gemeente mee kampt. Dat de categorie 'Samenleven en normen en waarden' zoveel kleiner is op lokaal dan op nationaal niveau suggereert dat de daaronder vallende problemen als onderdeel van een algemeen maatschappelijk of cultureel klimaat worden gezien. Iets soortgelijks geldt waarschijnlijk voor de op lokaal niveau klein uitvallende categorieën 'Inkomen en economie' en 'Werkgelegenheid': het economisch getij en de daarmee gepaard gaande fluctuaties in werkgelegenheid worden door burgers vooral als landelijk fenomeen gezien, hoewel er grote lokale verschillen in werkloosheid en economische ontwikkeling in Nederland bestaan (Van der Waal, 2015).

De gemeentelijke problematiek die burgers aankaarten, biedt kansen, maar toont ook de beperkte slagkracht van de gemeentelijke bestuurslaag. Enerzijds zijn problemen rond verkeer, de fysieke leefomgeving, criminaliteit en veiligheid goed op te pakken op lokaal niveau. Iets soortgelijks betreft deels de vooral in kleinere en landelijke gemeenten gesignaleerde problemen rond politiek en bestuur. Dit kan lokaal worden opgepakt, hoewel de door verschillende burgers gewenste professionalisering van de politiek en het bestuur in kleinere gemeenten vanwege schaalproblemen een grote uitdaging kan zijn. Dit roept de vraag op welke rol de lopende en reeds voltooide gemeentelijke herindelingen hierbij kunnen spelen. De professionaliseringsslag die daarmee kan worden gerealiseerd, zorgt mogelijk voor een toename in het vertrouwen in de gemeentepolitiek in kleine en landelijke gemeenten. Anderzijds zijn de handelingsperspectieven van de lokale politiek beperkt aangaande krimp van perifere gebieden en leegstand, en de vestiging van asielzoekerscentra. Veel burgers zien deze processen als belangrijkste probleem van hun gemeente, maar de lokale politiek heeft slechts in beperkte mate de mogelijkheden om daar wat aan te veranderen. Problematiek omtrent krimp, leegstand en asielzoekerscentra wordt dus weliswaar lokaal aangekaart, maar lijkt eerder een signaal richting provinciale, nationale of zelfs Europese overheden.

Al met al wijzen onze bevindingen op de substantiële meerwaarde van het LKO ten opzichte van het reeds langer lopende COB. Door middel van het LKO hebben we verschillende zorgen van burgers op lokaal niveau aan het licht gebracht. Daarmee bieden we relevante informatie voor zowel lokale als bovenlokale overheden. 
Een zekere overeenkomst tussen de zorgen van burgers en beleidsprioriteiten van overheden is immers van groot belang voor de representatieve functie van democratische politiek (Easton, 1965; Soroka \& Wlezien, 2010), de slagvaardigheid van democratisch bestuur (Dahl, 1989) en het vertrouwen in politieke instituties (Hetherington, 1998; Malhotra \& Kuo, 2008). Inzicht in de lokale zorgen van burgers kan daarom behulpzaam zijn bij het borgen van de legitimiteit en slagvaardigheid van politiek en bestuur op lokaal niveau, alsmede bij het borgen van het vertrouwen daarin.

\section{Literatuur}

CBS, Veiligheidsmonitor 2015, Den Haag: 2016. Op 17 juli 2016 gedownload op download.cbs.nl/pdf/veiligheidsmonitor-2015.pdf.

Charmaz, K., Constructing grounded theory. A practical guide through qualitative analysis, Londen: 2006.

Costa-Font, J. \& S. Greer (eds.), Federalism and decentralization in European health and social care, Houndmills: 2016.

Dahl, R.A., Democracy and its critics, New Haven: 1989.

Dekker, P. \& E. Steenvoorden, Continu Onderzoek Burgerperspectieven. Kwartaalbericht 2008/2, Sociaal en Cultureel Planbureau, Den Haag: 2008.

Dekker, P., L. de Blok \& J. de Hart, Continu Onderzoek Burgerperspectieven. Kwartaalbericht 2016/3, Sociaal en Cultureel Planbureau, Den Haag: 2016.

Dekker, P., T.W.G. van der Meer \& E. Steenvoorden, Continu Onderzoek Burgerperspectieven. Kwartaalbericht 2008/3, Sociaal en Cultureel Planbureau, Den Haag: 2008.

Dekker, P., T.W.G. van der Meer, P. Schyns \& E. Steenvoorden, Crisis in aantocht? Verdiepingsstudie Continu Onderzoek Burgerperspectieven 2008, Sociaal en Cultureel Planbureau, Den Haag: 2009.

Diaz-Serrano, L. \& A. Rodriguez-Pose, 'Decentralization and the welfare state. What do citizens perceive?', Social Indicators Research, 2015/2, p. 411-435.

Easton, D., A framework for political analysis, Chicago: 1965.

Exworthy, M. \& M. Powell, 'Decentralizing healthcare', A. Örtenblad, C. Abrahamson Löfström \& R. Sheaff (eds.), Management innovations for healthcare organizations. Adopt, abandon or adapt?, Volume 18, New York: 2015, p. 136-156.

Hetherington, M.J., 'The political relevance of trust', American Political Science Review, 1998/4, p. 791-808.

Kemmers, R., 'Channelling discontent? Non-voters, populist party voters, and their meaningful political agency', European Journal of Cultural and Political Sociology, 2017.

Koster, W. de \& J. van der Waal, 'Botsende opvattingen over etnische diversiteit en sociale orde. Hoe zijn verschillen tussen lager- en hogeropgeleiden te verklaren?', M. Bovens, P. Dekker \& W. Tiemeijer (eds.), Gescheiden werelden? Een verkenning van sociaal-culturele tegenstellingen in Nederland, SCP en WRR, Den Haag: 2014, p. 165-190.

Malhotra, N. \& A.G. Kuo, 'Attributing blame. The public's response to hurricane Katrina', Journal of Politics, 2008/1, p. 120-135.

Meer, T.W.G. van der, 'Legitimiteit en politieke steun', T.W.G. van der Meer \& H. van der Kolk (eds.), Democratie dichterbij, Stichting Kiezersonderzoek Nederland, Leiden: 2016, p. 12-22.

Ridder, J. den, I. Andriessen \& P. Dekker, Continu Onderzoek Burgerperspectieven. Kwartaalbericht 2017/2, Sociaal en Cultureel Planbureau, Den Haag: 2017. 
Ridder, J. den, P. Dekker, P. van Houwelingen \& E. Schrijver, Continu Onderzoek Burgerperspectieven. Kwartaalbericht 2016/1, Sociaal en Cultureel Planbureau, Den Haag: 2016.

Soroka, S.N. \& C. Wlezien, Degrees of democracy. Politics, public opinion, and policy, Cambridge: 2010.

Steenvoorden, E., 'De publieke stemming in 2008', P. Dekker, T.W.G. van der Meer, P. Schyns \& E. Steenvoorden (eds.), Crisis in aantocht. Verdiepingsstudie Continu Onderzoek Burgerperspectieven 2008, Sociaal en Cultureel Planbureau, Den Haag: 2009, p. 29-48.

Waal, J. van der, The global city debate reconsidered. Economic globalization in contemporary Dutch cities, Amsterdam: 2015.

Waal, J. van der \& E. Steenvoorden, 'Wat zijn de belangrijkste problemen in de gemeente?', T.W.G. van der Meer \& H. van der Kolk (eds.), Democratie dichterbij, Stichting Kiezersonderzoek Nederland, Leiden: 2016, p. 40-45.

Waal, J. van der, W. de Koster \& J. van Noord, 'Opleidingsverschillen in maatschappelijk onbehagen en wantrouwen in de politiek in Nederland, 1970-2012', G. Engbersen, M. Kremer \& E. Schrijvers (eds.), Middenklasse(n) onder druk?, SCP en WRR, Den Haag: 2017, p. 199-231. 